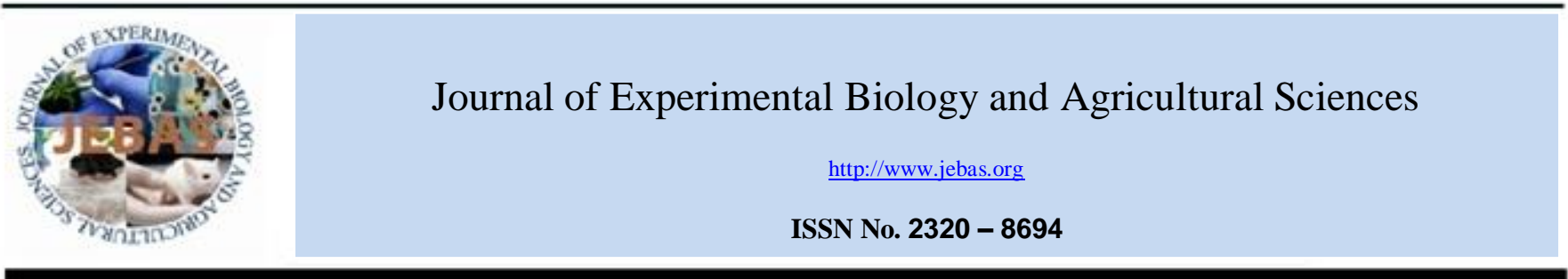

\title{
IMMUNE PROFILING OF GRAIN ADAPTED I-2 (GAI-2) PELLETED FEED VACCINE IN 6 WEEKS OLD COCKERELS IN VOM NIGERIA
}

Anthony N Egbuji ${ }^{1}$, John O. Ibu ${ }^{2}$, Ismaila A. Shittu ${ }^{1}$, Dauda G. Bwala ${ }^{1}$, Anne. S. Lohlum ${ }^{1}$, Josephine Kiagama ${ }^{1}$, Evelyn D. Dung ${ }^{1}$, Enurah L.Uwanibe ${ }^{1}$, Fatima B Mukaila ${ }^{1}$, Dung S Lokason ${ }^{1}$, Chinemerem. R Obene ${ }^{1}$, Choji A Kwanga ${ }^{1}$, Nicodemus M. Useh ${ }^{2}$, Paul A Abdul ${ }^{3}$, Usman Musa ${ }^{4}$, John A. Okoye ${ }^{5}$, Jude S. Rabo ${ }^{2}$

\footnotetext{
${ }^{1}$ National Veterinary Research Institute, Vom, Plateau State, Nigeria

${ }^{2}$ University of Agriculture, Makurdi, Benue State, Nigeria

${ }^{3}$ Ahmadu Bello University Zaria

${ }^{4}$ Usman Danfodio University Sokoto

${ }^{5}$ University of Nigeria Nsukka
}

Received - November 17, 2016; Revision - December 29, 2016; Accepted - June 07, 2017

Available Online - October 31, 2017

http://dx.doi.org/10.18006/2017.5(5).599.605

\section{KEYWORDS \\ Experimental trial \\ Pelleted feed vaccine, \\ 6 weeks old cockerels}

* Corresponding author

E-mail: wisemenvet@yahoo.com (Anthony Egbuji)

Peer review under responsibility of Journal of Experimental Biology and Agricultural Sciences.

Production and Hosting by Horizon Publisher India [HPI] (http://www.horizonpublisherindia.in/).

All rights reserved.

\begin{abstract}
In this study, a modified wet harvest of NDVI-2 virus strain with an EID $_{50}$ of $9.0 / \mathrm{ml}$ and a thermostability of 6 hours at $56^{\circ} \mathrm{C}$ was adsorbed to heat treated Digitalia iburua which served as the virus carrier and was used to prepare pelleted feed vaccine. In this trial, 100 (six weeks old) cockerels were divided into five groups of twenty each. They all were vaccinated against other diseases except Newcastle disease (ND). Group 1 was not given the pelleted feed vaccine and served as the vaccine control, while groups 2, 3, and 4 were feed with 10,15, and 20 grams per birds respectively while group 5 was treated with the conventional NDVI-2 through the intra ocular route. Groups 2, 3 and 4 were given booster doses at different intervals. The detectible antibody was analysed using haemagglutination inhibition (HI) test. The geometric mean titre of protective antibody response in cockerel vaccinated with GAI-2 pelleted feed vaccine compared favourably with the conventional NDVI-2. Groups 2 to 5 were later challenged with wild virulent field virus (Kudu 113 ND strain) and the antibody response was astronomical, with group 2 recording the highest geometric mean titre of 2352.5 post challenge. Thus,
\end{abstract}

All the article published by Journal of Experimental Biology and Agricultural Sciences is licensed under a Creative Commons Attribution-NonCommercial 4.0 International License Based on a work at www.jebas.org.

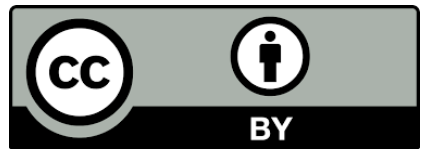


the GA I-2 pelleted feed vaccine could be an excellent alternative to the conventional vaccination method, since the stress associated with handling of individual birds will be greatly minimized. The significance of the rapid increase in the antibody titre when challenged with wild virus strain is discussed.

\section{Introduction}

Newcastle disease (ND) is an acute, highly contagious, rapidly spreading viral disease affecting birds of all ages. It varies widely in type and severity of symptoms (Alexander, 2000; Abdu, 2005; Saidu et al., 2006). The global impact of ND is enormous and it is responsible for international trade barriers of poultry and poultry products (Alexander, 2003). It is a devastating disease of poultry particularly in village and backyard poultry and a major constraint to developing poultry industry (Alexander, 1988; Spradbrow,1993), where control remains extremely difficult or even impossible (Alexander \& Jones, 2001).

In Nigeria, Newcastle disease was first reported by Hill et al. (1953). Since then, it has continued to be a major setback in the development of rural poultry production. The application of biosecurity measures as a control option is possible however; its application in an endemic region is very difficult. Thus, vaccination remains the only possible alternative. Though vaccines are available for the control of this disease, they are mostly geared toward the control of ND in commercial flock. In developing countries, rural backyard poultry are rarely vaccinated against ND.

Current conventional vaccination programs for ND virus control include the use of either low-virulent live-virus vaccines or inactivated vaccines to induce protective immunity while producing minimal adverse effects in birds (Zoth et al., 2008). Birds may also be inoculated with eye drops containing vaccines based attenuated viruses. Vaccination using non virulent ND strains protects susceptible birds against ND disease, and antibodies are produced either locally or systemically or both (Zoth et al., 2008).

The commercial potential of rural poultry is enormous, but an occasional annual loss resulting from ND outbreaks discourages huge investment in rural backyard poultry production. Vaccination against Newcastle disease has been reported as the major safe guard against outbreaks especially in countries with endemic very virulent Newcastle disease (vvND) and where highly efficient biosecurity measures are impossible to apply (Usman, 2002), especially in rural situation in developing countries due to the nomadic and free range rearing of village poultry.

NDVI-2 vaccine was originally developed for the control of ND in rural flocks where cold chain storage is almost absent, The development of GAI-2 feed vaccine is believed to be a better vaccination alternative to conventional NDVI-2 in terms of heat resistant and immunogenicity. Therefore, present study has been carried out to access the immune profiling of grain adapted I-2 (GAI-2) pelleted feed vaccine in 6 weeks old cockerels in Vom Nigeria

\section{Materials and Methods}

\subsection{Proximate and antinutritional analysis}

Proximate and antinutritional tests were carried out on Digitalia iburua using Association of Official Analytical Chemists (AOAC 1990) method. The proximate analysis of the Digitalia iburua sample for protein, crude fibre, total ash ,moisture were carried out in triplicate using the method described by Association of Official Analytical Chemists (AOAC, 1990).

\subsection{Moisture content}

The moisture content determination was carried out gravimetrically after oven drying the Digitalia iburua sample at $105^{\circ} \mathrm{C}$ to a constant weight.

\subsection{Crude protein}

Nitrogen content of the Digitalia iburua sample was determined using the Kjeldhal method and the titrated value of the nitrogen multiplied by 6.25 as a conversion factor.

\subsection{Lipid content}

The determination of crude fat (Lipid) content of the Digitalia iburua sample was carried out by extraction with petroleum ether in a soxhlet apparatus and the fat content determined gravimetrically.

\subsection{Ash content}

Ash content was determined by heating 2 grams of Digitalia iburua sample in a muffle furnace at $550^{\circ} \mathrm{C}$ to a constant weight.

\subsection{Crude fibre}

The determination of crude fibre of the Digitalia iburua sample was carried out using an acid-alkaline gravimetric method in line with the principles of AOAC (1990). 


\subsection{Nitrogen free extract}

The nitrogen free extract (NFE) of the Digitalia iburua was obtained by difference i.e. the sum of crude protein (CP), crude fat (CF), and Ash subtracted from one hundred.

\subsection{Determination of antinutritional factors}

\subsubsection{Determination of oxalate}

Oxalate was extracted from powdered sample of Digitalia iburua and precipitated as calcium salt. The precipitate was dissolved in $25 \%$ sulphuric acid and the concentration of oxalate determined by titration with $0.01 \mathrm{~N}$ potassium permanganate (AOAC, 1990).

\subsubsection{Determination of Tannis}

This was carried out spectrophotometrically by the method of Joselyn (1970). The sample of the Digitalia iburua was extracted by refluxing with $50 \%$ ethanol in a soxhlet apparatus for 18 hours. The extract was then dissolved in $25 \mathrm{ml}$ water treated according to standard procedure and absorbance read at $760 \mathrm{~nm}$

\subsubsection{Determination of Phytic acid}

Phytic acid (Inositol hexaphosphate) content of the Digitalia iburua was determined by the modified method of AOAC(1990). For this, two grams (2g) of Digitalia iburua sample was extracted according to standard procedure and absorbance read at $476 \mathrm{~nm}$ or $640 \mathrm{~nm}$.

\subsubsection{Modification of thermostable NDVI-2 virus}

NDVI-2 parent virus with a thermostability of 3 hour at $56^{\circ} \mathrm{Cwas}$ subjected to series of heat treatment in water bath. The heating duration was standardized after a modification of the heating method of Ibu et al. (2010). $1 \mathrm{ml}$ of NDVI-2 parent stock with a thermostability of 3 hours at $56^{\circ} \mathrm{C}$ was placed into each 8 bijou bottles and allowed to stand in a water bath at $56^{\circ} \mathrm{C}$ for 8 hours. After every hour one bijou bottle is removed from the water bath and placed in the refrigerator at $+4^{\circ} \mathrm{C}$ until the $8^{\text {th }}$ hour when the last bijou bottle was removed from the water bath and stored at $+4^{\circ} \mathrm{C}$. At the end of the heat exposure the aliquots were inoculated into 10day old embryonated chicken eggs at $0.1 \mathrm{ml}$ per egg and incubated at $37^{\circ} \mathrm{C}$ for 96 hours, with daily candling, to assess its infectivity. On the death of any inoculated embryonated eggs following candling, the allantoic fluid was harvested and checked for haemagglutination activity.

The embryonated eggs inoculated with virus from the aliquot with the highest heat treatment duration showing haemagglutination was harvested and subsequently used for further heat treatment in water bath at $56^{\circ} \mathrm{C}$ for 8 hours. After repeated three passages in embryonated chicken eggs and three heat treatments at $56^{\circ} \mathrm{C}$, a thermostable heat resistant virus with a thermostability of 6 hours at $56^{\circ} \mathrm{C}$ was produced and harvested, and used for the preparation of GAI-2 pelleted feed vaccine.

\subsubsection{Preparation of virus carrier for GAI-2 pelleted feed vaccine}

$2.5 \mathrm{~kg}$ of Digitalia iburua was soaked in 10 liters of clean sterile water overnight, After which it was sieved and boiled in equal volume of water at $100^{\circ} \mathrm{C}$ and the boiling mixture stirred for ten minutes. Thereafter the cooked Digitalia iburua was dried and roasted in an oven for 4 hours at $100^{\circ} \mathrm{C}$. The complete dried Digitalia iburua was then allowed to cool before it was blended into fine particles, using a manual blender.

\subsubsection{Virus mixture}

2.5 litres of modified NDVI-2 virus harvested from infective allantoic fluid of embryonated chicken eggs after three passage with a thermostability of 6 hours at $56^{\circ} \mathrm{C}$ and a titre of $9.0 \log _{10}$ EIDso per $\mathrm{ml}$ was added to $100 \mathrm{ml}$ of peptone. $100 \mathrm{ml}$ of antibiotic and antimycotic suspension made up of (penicillin 100000 i.u, streptomycin $5 \mathrm{~g}$ streptomycin base, gentamycin $280 \mathrm{mg} / \mathrm{ml}$, and amphotericine B250 $\mu \mathrm{g} / \mathrm{ml}$ ). This mixture was added to $2.5 \mathrm{~kg}$ of the blended Digitalia iburua and mixed. The mixture was allowed to stand for 10 minutes for complete adsorption. The adsorbed virus mixture was pelleted using an electric powered pelleting machine. The generated pellets were stored at $-80^{\circ} \mathrm{C}$. The $E I D_{50}$ of the pelleted vaccine was determined using the Karber method (1931).

\subsection{Experimental Trial}

The facility for the trial was provided by National Veterinary Research experimental station, at Vom, Plateau state Nigeria. The pen and cages were fumigated with formaldehyde and potassium permanganate, and disinfected with potassium peroxomonosulphate $50 \% \mathrm{~m} / \mathrm{m}$. The facility was rested for two weeks, after treatment with virucidal agent, before stocking with the birds. Movement into the pens were restricted and provision for foot dip was provided in each of the experimental house and application of the "all in all out rule" in the facility during the study period was strictly adhered to during sample collection.

The birds were divided into 5 groups of 20 cockerels each viz: Group 1- unvaccinated (control) Group 2 -vaccinated with 10gm of pelleted feed vaccine per bird and booster dose administered at day 14 Group 3 - vaccinated with $15 \mathrm{gm}$ of pelleted feed vaccine and booster dose administered at day 14 Group 4 vaccinated with $\mathbf{2 0 g m}$ of pelleted feed vaccine per bird, Group 5 - vaccinated with NDVI-2 conventional vaccine. 
Table 1: Proximate analysis: [weight (g) per 100 grams Digitalia iburua sample]

\begin{tabular}{|c|c|c|c|c|c|c|c|c|}
\hline Sample & MOISTURE & $\begin{array}{c}\text { Crude } \\
\text { PROTEIN }\end{array}$ & $\begin{array}{l}\text { Crude } \\
\text { FIBRE }\end{array}$ & $\begin{array}{l}\text { Crude } \\
\text { FAT }\end{array}$ & ASH & NFE & $\mathbf{C A}$ & Phosphorous \\
\hline Digitalia & 4.60 & 10.49 & 7.23 & 2.88 & 14.15 & 65.25 & 0.14 & 0.08 \\
\hline
\end{tabular}

Table 2: Anti-nutritional screening weight (mg) per 100 grams digitalia iburua sample

\begin{tabular}{|lccc|}
\hline Sample & PHYTIC ACID & OXALATE & TANNINS \\
\hline Raw Acha & 49.34 & 20.00 & 0.827 \\
\hline
\end{tabular}

The birds were housed in separate cages of 10 birds per cage and each group in duplicate. Blood samples were collected from all the birds for determination of presence of ND antibody titre, prior to the administration of the GAI-2 pelleted feed vaccine. Following vaccination, birds were bled 2 weeks, 3 weeks, 4 weeks and 6 weeks post vaccination (Table 4 )

\subsection{Serum sample collection and analysis}

Blood sample was collected aseptically from the bird one week after administration of GAI-2 feed pelleted vaccine. Sera samples were collected and used to determine the presence of ND antibody titres using haemagglutination inhibition $(\mathrm{HI})$ test

\subsection{Haemagglutination and haemagglutination inhibition}

Haemagglutination and haemagglutination inhibition tests were carried out on the collected sera samples as per method described by the OIE Manual (OIE, 2010). In performing the HI, the HA titres of standard NDV antigen was determined as described by Allan \& Gough (1974) and diluted to contain 4HA units. The reconstituted antigen containing the 4HA units was used in the determination of test sera titres in a HI test. The HI titre for each screened sera was determined and expressed in $\log 2$, and the geometric mean titre calculated for each group that was screened. Any HI titre of $\geq 2 \log 2$ was considered positive and HI titre $\leq 2$ $\log 2$ were considered negative. Each group geometric antibody titre was determined using Pedro Villegas table.

\section{Result}

Proximate and antinutritional factors analysis showed that Digitalia iburua has low moisture, fat, and calcium content. It equally showed low content in terms of phytic acid, oxalate and tannins content (table1 and 2)

The result of the proximate analysis of Digitalia iburua revealed low; moisture content, crude proteins, crude fat, ash, nitrogen free extract calcium and phosphorus.
Antinutritional screening equally showed low phytic acid, oxalate and tannins content all of which are natural viral inhibitors in grain. Therefore, based on these results Digitalia iburua was subsequently subjected to heat treatment for complete inactivation of these natural inhibitors. Afterwards, the heat treated Digitalia iburua was adsorbed to modified virus harvest for the preparation of grain adapted feed vaccine, and the produced pelleted feed vaccine $E I D_{50}$ compared with the $E I D_{50}$ of standard NDVI-2 vaccine in an in-vitro assay prior to on-station trial in 6 weeks old cockerels.

Viral content assay of the pelleted feed vaccine produced using heat treated Digitalia iburua are shown in (tables 3). The obtained $E I D_{50}$ was comparable with $E I D_{50}$ of standard NDVI-2 vaccine. The resultant titre $E I D_{50}$ of $\log _{10} E I D_{50} 8.5$ per dose obtained after pelleted feed vaccine production showed that the heat treated Digitalia iburua was 3 logarithms above minimal acceptable dose range for NDVI-2 standard vaccine of $\log _{10} E I D_{50} 5.5$ per dose. The result showed that heat treated Digitalia iburua when adsorbs with the modified NDVI-2-6 virus derivative, an $E I D_{50}$ that was comparable with standard NDVI-2 vaccine recommended dose for field vaccine was obtained (Table 3).

Table 3: EIDso determination result for screening of GAI-2 feed pelleted vaccine

\begin{tabular}{|lc|}
\hline Sample & EID $_{\mathbf{5 0}} / \mathbf{g m}$ \\
\hline $\mathrm{NDVI}_{2}$ (positive control) & 9.0 \\
\hline $\begin{array}{l}\text { Soaked parboiled roasted Digitalia ibura } \\
\text { after adsorption }\end{array}$ & 8.5 \\
\hline
\end{tabular}

Table 4 shows the result of the on-station trial of grain adapted feed vaccine in chicken (GMT) in relation to period of administration. The result was significantly different $(\mathrm{p}<0.05)$ from each other. The highest mean value was found in the 
Table 4 Geometric mean antibody titre result post administration of pelleted $\mathrm{GAI}_{2}$ vaccine to 6 weeks old cockerels

\begin{tabular}{|c|c|c|c|c|c|c|c|c|c|c|}
\hline Group & $\begin{array}{l}\text { Number } \\
\text { of birds } \\
\text { per group }\end{array}$ & $\begin{array}{c}\text { Pre- } \\
\text { Vaccination } \\
\text { titre }\end{array}$ & $\begin{array}{c}\text { Quantity of } \\
\text { pelleted feed } \\
\text { vaccine given }\end{array}$ & $\begin{array}{c}\text { Booster } \\
\text { period }\end{array}$ & $\begin{array}{c}\text { week } 2 \\
\text { PV }\end{array}$ & $\begin{array}{c}\text { week } 3 \\
\text { PV }\end{array}$ & $\begin{array}{c}\text { week } 4 \\
\text { PV }\end{array}$ & $\begin{array}{c}\text { Titre drop } \\
\text { recorded } \\
\text { at week } 4\end{array}$ & $\begin{array}{l}\text { week } 5 \\
\text { challenge }\end{array}$ & $\begin{array}{l}\text { Week6 post } \\
\text { challenge } \\
\text { antibody titre }\end{array}$ \\
\hline $\begin{array}{l}\text { Unvaccinated } \\
\text { Group1 }\end{array}$ & 20 & $\leq 2 \log _{2}$ & Nil & Nil & $\leq 2 \log _{2}$ & $\leq 2 \log _{2}$ & 2 & 2 & challenge & $\begin{array}{c}\text { 100\% Mortality } \\
\text { within } 96 \text { hrs }\end{array}$ \\
\hline Group2 & 20 & $\leq 2 \log _{2}$ & $10^{\circ} \mathrm{gm}(200 \mathrm{gm})$ & Day14 & 45.3 & 147 & 108 & 39.4 & challenge & 2352.5 \\
\hline Group3 & 20 & $\leq 2 \log _{2}$ & $15 \mathrm{gm}(300 \mathrm{gm})$ & Day21 & 207 & 776 & 724 & 52 & challenge & 315.2 \\
\hline Group4 & 20 & $\leq 2 \log _{2}$ & $20 \mathrm{gm}(400 \mathrm{gm})$ & Nil & 29.9 & 119.4 & 96.8 & 22.6 & challenge & 1351.2 \\
\hline Group5 & 20 & $\leq 2 \log _{2}$ & $\begin{array}{c}\text { Administer } \\
\mathrm{NDVI}_{2} \text { Standard } \\
\text { vaccine }\end{array}$ & Nil & 181 & 157 & 120.2 & 36.8 & challenge & 548.7 .3 \\
\hline
\end{tabular}

Table 5: Results of statistical analysis of on-station trial of grain adapted feed vaccine in chicken.

\begin{tabular}{|lc|cccccc|}
$\begin{array}{l}\text { Quantity of feed vaccine per } \\
\text { administration (group) }\end{array}$ & $\begin{array}{c}\text { Pre- } \\
\text { vaccine }\end{array}$ & $\begin{array}{c}\text { 2wks post } \\
\text { vaccine }\end{array}$ & $\begin{array}{c}\text { 2wks post } \\
\text { challenge }\end{array}$ & 3 wks & 4 wks & F-test & P \\
\hline Pre-vaccination(1) & $1.1 \pm 0.4$ & $1.1 \pm 0.4$ & $1.1 \pm 0.4$ & $1.1 \pm 0.4$ & $1.1 \pm 0.4$ & - \\
10 gm, 14 days to boost (2) & $1.1 \pm 0.4$ & $4.2 \pm 2.0^{\mathrm{a}}$ & $11.2 \pm 1.6^{\mathrm{b}}$ & $5.9 \pm 1.7^{\mathrm{c}}$ & $5.9 \pm 1.4^{\mathrm{c}}$ & 37.359 & 0.001 \\
15 gm, 21 days to boost (D) & $1.1 \pm 0.4$ & $4.3 \pm 2.0^{\mathrm{a}}$ & $8.3 \pm 2.6^{\mathrm{b}}$ & $4.9 \pm 2.2^{\mathrm{a}}$ & $4.9 \pm 1.3^{\mathrm{a}}$ & 9.604 & 0.001 \\
20 gm, no day to boost (4) & $1.1 \pm 0.4$ & $4.8 \pm 2.2^{\mathrm{a}}$ & $10.5 \pm 2.9^{\mathrm{b}}$ & $4.7 \pm 1.8^{\mathrm{a}}$ & $3.4 \pm 1.8^{\mathrm{a}}$ & 26.829 & 0.001 \\
NDVI2 Standard vaccine(5) (G) & $1.1 \pm 0.4$ & $3.1 \pm 1.8^{\mathrm{a}}$ & $9.1 \pm 2.5^{\mathrm{b}}$ & $3.4 \pm 1.4^{\mathrm{a}}$ & $4.0 \pm 1.6^{\mathrm{a}}$ & 29.719 & 0.001 \\
\hline
\end{tabular}

Row with different superscripts are statistically significantly different at $p<0.05$

2 weeks post challenge. This was attributed to the systemic response of the vaccinated birds to wild ND viral challenge.

\subsection{Effect of Vaccination on Birds}

The birds were divided into twenty in each group and were administered the GAI-2 adapted pelleted feed vaccine, and the standard NDVI-2 vaccine.

Results of the on-station trial of grain adapted feed vaccine in chicken (GMT) is as presented on table 5 . There were significant differences $(\mathrm{p}<0.05)$ in the mean result in all the quantity of feed vaccine administration (groups) across the period. The highest mean is obtained in the 2 weeks post challenge in each of the groups.

Table 6 showed the result of the statistical analysis during the onstation trial of grain adapted feed vaccine in chicken (GMT) in relation to pre-vaccination, two weeks post-vaccination, and two
Table 6 Results of on-station trial of grain adapted feed vaccine in chicken (GMT)

\begin{tabular}{|llll|}
\hline Period & Mean \pm SD & F-test & P \\
\hline Pre-vaccination & $1.1 \pm 0.3^{\mathrm{a}}$ & 330.726 & 0.001 \\
\hline $\begin{array}{l}2 \text { weeks post } \\
\text { vaccination }\end{array}$ & $3.9 \pm 2.2^{\mathrm{b}}$ & \\
\hline $\begin{array}{l}2 \text { weeks post } \\
\text { challenge }\end{array}$ & $10.2 \pm 2.2^{\mathrm{c}}$ & \\
$\begin{array}{l}\text { Row with different superscripts are statistically significantly } \\
\text { different at } p<0.05\end{array}$
\end{tabular}

weeks post challenge There was significant difference of $(\mathrm{p}<0.05)$ from each other. The highest mean value was found in the 2 weeks post challenge this sequel to astronomical rise in the antibody production due challenge activity with the Kudu 113 strain. 


\section{Discussion}

Researchers at University of Queensland in Australia carried out extensive research on ND virus and as a result, an avirulent thermostable virus was developed to control ND in rural poultry (Spadbrow \& Sabine, 1995; Bensink \& Spradbrow 1999). The NDVI-2 vaccine strain which requires less cold chain handling has been extensively tested to protect rural poultry against ND in some Asian and African countries (Tu et al., 1998; Wambura et al., 2000; Wambura et al., 2007).

Since ND affect chickens of all ages and due to free range nature of village poultry production system where chickens of all ages scavenge for food together, it becomes difficult to administer ND vaccine through water or intraocularly. The search for a suitable food material as vaccine virus carrier that will simplify vaccination in rural poultry therefore becomes imperative, and several attempts have been made by researchers to use food as vaccine virus carrier for thermostable ND vaccine. In Asia Africa and Australia paddy rice, cooked white rice and cooked parboiled rice has been used as suitable alternatives (Samuel \& Spradbrow, 1989; Spradbrow, 1992; Ibrahim et al., 1992; Wambura et al., 2007), with a thermostability of 3 hour at $56^{\circ} \mathrm{C}$.

In this study, Newcastle disease virus vaccine (NDVI-2) was subjected to heat treatment and underwent three different passages in embryonated chicken eggs. A resultant harvest with a thermostability of 6 hours at $56^{\circ} \mathrm{C}$ was achieved. The modified virus harvest in the presence of antibiotics, antimycotic and stabilizer was adsorbed to heat treated Digitalia iburua(locally known as Acha) without deterioration. This was pelleted to produce the grain adapted (GAI-2) pelleted feed vaccine which is more durable under field condition.

The result of the antibody response after vaccination with GAI-2 showed a steady increase in the geometric mean titre by the second and third week post vaccination. However, a sudden drop in geometric mean titre was observed on the fourth week, this could probably be attributed to unascertained natural event or stress associated with handling during bleeding for blood sample collection. Despite the drop in the mean antibody titre, 10 birds from each group were challenged on the fifth week with wild virulent field strain of Newcastle virus (kudu 113strain) with a $\log 10$ EID508.7 at a dose of $0.1 \mathrm{ml}$ per bird intramuscular The unvaccinated group showed $100 \%$ mortality within 96hours while the vaccinate groups i.e. those vaccinated with both conventional and the modify GAI-2 pelleted feed vaccine showed an astronomical rise in their geometric antibody titres and mortality was not recorded in these groups.

The result from table 4 revealed that birds vaccinated with 10 gram per bird and boosted two weeks later gave a highest antibody response (2352.5) compared to groups3 (315.2), group 4 (1351.2) and group 5 (548.73). This result is similar to observations of Abdi et al., (2016) where they observed that repeated vaccine administration induces progressively higher $\mathrm{HI}$ antibody titer that could correspond to high levels of protection Although all the groups that were challenged with virulent field strain had an astronomical rise in the geometric mean titre, the results of birds in group 3 showed that they did get enough of the pelleted feed, thus the low mean antibody titre. From the above, it could be recommended that 10 grams per bird be administered and a booster dose given at 14days after the initial vaccination

This result showed that vaccination using the newly developed vaccine GAI-2 will confer protection to birds against wild virulent forms of field ND virus, especially in regions where ND outbreak is a challenge to scavenging poultry farming. Therefore, almost sixty two years sequel to the first recorded outbreak in Nigeria, ND has persistently been a setback to rural scavenging poultry development. Thus, to mitigate against consequences of occasional out breaks in rural unvaccinated flock, it is imperative that a compulsory strategic vaccination be initiated, and this must be geared towards ND eradication especially in endemic regions where bio-security measures which includes bio-exclusion and bio-containment methods of control are impossible control options.

\section{Acknowledgements}

The authors are grateful to the Executive Director, National Veterinary Research Institute, Vom, for permission to publish this paper and Competitive Agricultural Research Grants Scheme (CARGS), under Agricultural Research Council of Nigeria $(\mathrm{ARCN})$, for providing the funds for this research project. The technical assistance of Davou Nyam, and Haruna Dagwong are well appreciated.

\section{Conflict of interest}

All the authors declare that there is no conflict of interest.

\section{References}

Abdi RD, Amsalu K, Merera O, Asfaw Y, Gelaye E, Yami M, Sori T (2016) Serological response and protection level evaluation in chickens exposed to grains coated with I2 Newcastle disease virus for effective oral vaccination of village chickens. BMC Veterinary Research 12:150. DOI: https://doi.org/10.1186/s12917-016-0785-6.

Abdu PA (2005) Evolution and the pathogenicity of Newcastle Disease virus and its implication for diagnosis and control. Proceedings of the workshop on improved Disease Diagnosis, Health, Nutrition and Risk management Practice in Poultry, held 
on $29^{\text {th }}$ November to $1^{\text {st }}$ December 2005 at Ahmadu Bello University Zaria, Nigeria.

Alexander DJ (1988) Newcastle Disease: Methods of spread, In: Alexander DJ, Kluwer MA (Eds.), Diseases of Poultry, USA, Boston: Academic Publishers, Pp: 256-272.

Alexander DJ (2000) Newcastle disease and other avian paramyxoviruses. Revue scientifique et technique (International Office of Epizootics) 19: 443-462.

Alexander DJ (2003) Newcastle disease, other Paramyxoviridae and Pneumovirus Infections. In: Saif YM, Barnes HJ, Glisson JR, Fadly AM, McDougald LR, Swayne DE (Eds.), Diseases of Poultry, 11th edn, USA, Ames: Iowa State University Press Pp: 63-100.

Alexander DJ, Jones RC (2001) Newcastle disease. In: Jordan FTW, Pattison M, Alexander DJ, Faragher T (Eds.), Poultry Diseases, London: W.B. Saunders, Harcourt Publishers, Pp: 55-63.

Allan WH, Gough RE (1974) A standard haemagglutination inhibition test for Newcastle disease. Veterinary Record 95:147-149.

Association of Official Analytical Chemists (AOAC 1990) method. Available at https://archive.org/stream/gov.law.aoac.methods.1.1990/aoac.met hods.1.1990_djvu.txt access on 22nd January, 2017.

Bensink Z, Spradbrow PB (1999) Newcastle disease virus strain I2- a prospective thermostable vaccine for use in developing countries. Veterinary Microbiology 68:131-139.

Hill OH, Olives SO, Wilde JKH (1953) Newcastle Disease in Nigeria. British Veterinary Journal 9: 11-13

Ibrahim AL, Ideris A, Babjee AM (1992) An overview of the use of food-based Newcastle disease vaccine in Malaysia. In: Spradbrow PB (Ed.), Proceedings of an international workshop, Kuala Lumpur, 6-10 October 1991. Canberra, ACIAR proceedings No. 39:75-79.

Ibu OJ, Okoye JOA, Baba SS, Shoyinka SVO, Chah KF, Antiabong J, Eze D, Salihu EA, Oladele, SB (2010) Thermostability profile of Newcastle Disease viruses isolated from wild birds in central Nigeria and selection of a thermostable clone. International Journal of Poultry Science 9:791-794.

Joselyn MN (1970) Tannis and related phenols In: Methods in
Food Analysis. Academic Press New York, USA,. Pp701-725.

Karber G (1931) Beitrag zur kollektiven behandlung phamakoloischer reihenversuche. Archive für Experimentelle Pathologie Pharmakologie 162: 480-483.

Office International des Epizootics (2010) Newcastle Disease, Manual of standard for diagnostic tests and vaccines. Office International des Epizootics(OIE), Paris, Pp. 221-232.

Saidu L, Abdu PA, Tekdek LB, Umoh JU, Usman M, Oladele SB (2006) Newcastle disease inNigeria. Nigerian Veterinary Journal 2: 23-32.

Samuel JL, Spradbrow PB (1989) Persistence of the V4 strain of Newcastle disease in an open-range flock of chickens. Veterinary Record 124: 193-196

Spadbrow PB, Sabine M (1995) Australian studies on Newcastle disease virus. The French heritage. Veterinary Microbiology 46: 15-19.

Spradbrow PB (1993) Newcastle disease in village chickens. Poultry Science Review 5: 57-96.

Spradbrow PB (1992) A review of the use of food carriers for the delivery of oral Newcastle disease vaccine. In: Spradbrow PB (Ed.) Proceedings of an international workshop, Kuala Lumpur, 610 October 1991. Canberra, ACIAR proceedings No. 39: 18-20.

Tu TD, Phuc KV, Dinh NTK, Quoc DN, Spradbrow PB (1998) Vietnamese trials with a thermostable Newcastle disease vaccine (strain I-2) in experimental and village chickens. Preventive Veterinary Medicine 34: 205-214.

Usman M (2002) Effects of vaccination of chickens against Newcastle diseases with thermostable V4 and La Sota vaccines. M.Sc. Thesis submitted to the Department of Veterinary Surgery and Medicine, Ahmadu Bello University, Zaria, Nigeria.

Wambura PN, Kapaga AM, Hyera JMK (2000) Experimental trials with thermostable Newcastle disease virus (strain I-2) in commercial and village chickens in Tanzania. Preventive Veterinary Medicine 43: 75-83.

Wambura PN, Meers J, Spradbrow PB (2007) Survival of avirulent thermostable Newcastle disease virus (strain I-2) in raw, baked, oiled, and cooked white rice at ambient temperatures. Journal of Veterinary Science 8: 303-308.

Zoth SC, Gómez E, Carrillo E, Berinstein A (2008) Locally produced mucosal IgG in chickens immunized with conventional vaccines for Newcastle disease virus. Brazilian Journal of Medical and Biological Research 41: 318-323. 